\title{
Rzeczywistość przedstawiona w poezji stanu wojennego
}

Agnieszka Dębska 


\section{Agnieszka Dębska}

\section{Rzeczywistość przedstawiona w poezji stanu wojennego}

$\mathrm{U}$ twory z okresu stanu wojennego w Polsce nie cieszą się uznaniem historyków literatury. Zazwyczaj oskarża się je o tendencyjność i schematyzm, zapominając przy tym, że wspomniane cechy stanowią wyróżniki okolicznościowej literatury politycznej, do której wiersze z lat 1982-1984 w znacznej większości przynależą.

Do najczęściej wykorzystywanych przez tę poezję sposobów mówienia o rzeczywistości stanu wojennego nalcży przywoływanie romantycznych mitów i religijnych analogii. Ujmowany w tych kategoriach stan wojenny jawi się jako zjawisko już znane, a zarazem oswojonc.

Istnicje wszakże spora grupa utworów, które nie posługują się tego typu schematami. Próbują one uchwycić specyfikę doświadczenia stanu wojennego i znaleźć dla jej wyrażenia odpowicdni język. Tym samym kładą one nacisk na to, co w opisywanym doświadczeniu niepowtarzalne ${ }^{1}$.

Spośród motywów pojawiających się w utworach, które w taki właśnie sposób próbują pokazać rzeczywistość stanu wojennego, wyróżniam cztery grupy tematyczne — skupione wokół obrazów ulicy, domu, więzienia oraz rodziny.

\footnotetext{
' Zwracal na to uwagę S. Barańczak w artykule Norwid nie chce podpisać volkslisty („Wezwanie” 1983 nr 5), w którym taki sposób postrzegania rzeczywistości, uwzględniający niepowtarzalność, swoistość zjawisk oglądanych przez pryzmat indywidualnych doświadczeń, nazywa perspektywą Pojedynczego Obserwatora.
} 


\section{Sceneria wojenna}

Wiele utworów, zwłaszcza powstających w pierwszych dniach stanu wojennego, próbuje opisać wojenny pejzaż. Składa się nań odmieniony obecnością czołgów i patroli wygląd miejskich ulic oraz sceneria surowej zimy. Do najczęściej pojawiających się obrazów należy czołg stojący na skrzyżowaniu i grzejący się przy koksownikach żołnierze:

Ta mroźna cisza miasta mego

Czołgi stojące niby cienie

Zołnierze jak niepewni swego

Schylają głowy nad płomieniem

Ernest Bryll Scena przy ognisku²

To nasi żołnierze żołnierze

Opancerzone pojazdy na mrozie

Na skrzyżowaniach sumień żołnierze, żołnierze (...)

Mat. [Mieczysława Buczkówna] Boże Narodzenie $1981^{3}$

Żołnierze na skrzyżowaniu

Azji i Europy

Grzali czerwone ręce

Nad węglowym piecem

Te Jot [Tomasz Jastrun] Do syna

Jak wynika z przytoczonych przykładów, wyprowadzone z realiów „skrzyżowanie” niezwykle łatwo się metaforyzuje. Wierszy opisujących podobny pejzaż jest w poezji stanu wojennego bardzo dużo. Jak zauważył Piotr Bratkowski, wojenna sceneria jest atrakcyjna przez swą niecodzienność. W przypadku wierszy z tego okresu „możemy mówić o swoistej fascynacji pejzażem, zmianą s k ó r y świata" (podkr. P. B. $)^{5}$.

Kolejnym elementem wojennej scenerii dostrzeżonym przez tę poezję jest cisza, która panuje na wyludnionych ulicach. Cisza oraz mróz sprawiają, że charakterystycznym dźwiękiem staje się chrzęst żołnierskich butów:

Czasami tylko głucho śnieg zachrzęści

Noga patrolu nagle poruszony.

M. K. L'ordre règne à Varsovie ${ }^{6}$

${ }^{2}$ Poezja stanu wojny [wyb. i opr. Z. Zaremba,] New York 1983 Bicentennial Publishing Corp. „Nowy Dziennik", s. 31.

${ }_{3}^{3}$ Poezja stanu wojennego. Antologia, tom przygotowali: Inga [I. Smolka], Jot Em [J. Markiewicz], Spectator [L. Szaruga], London 1982 Puls, s. 81.

${ }^{4}$ Tamże, s. 20.

${ }^{5}$ M. Mokotowski [P. Bratkowski], Gdy upiory grasujq, rozum się budzi, „Wezwanie” $1982 \mathrm{nr}$ 1, s. 74.

${ }^{6}$ Poezja stanu wojernego..., s. 78. 


\section{(...) teraz w ścianie}

odbija się martwy śnieg,

chrzęści pod podkutymi butami.

Ryszard Krynicki Tivarzq do ściany ${ }^{7}$

Śnieg, mróz, mrok wywodzące się z grudniowych realiów uzyskują w tej poezji rozmaite znaczenia metaforyczne. Śnieg służy do budowania symboliki męczeństwa - w niezwykle często przez tę poezję wykorzystywanym obrazie krwi na śniegu:

Znów grudzień! Biały śnieg i krew czerwona

Polska!

[autor nieznany] Pamięci gómików zabitych w kopalni Wujek $w$ Polsce $w$ grudniu $1981 r^{8}$

krew przebiła bielmo śniegu

Anonim [Krzysztof Karasek] „krew krew na mundurze..."

Jak boli ta biel

z przestrzeloną piersią

Anna Kamieńska Grudzień $1981^{10}$

Pokrywający wszystko śnieg jest także znakiem zapomnienia, negatywnie wartościowanego spokoju:

Nasi zabici pod śniegiem pod śniegiem

Wszystko pod śniegiem pod śnicgiem

Mat. [Mieczysława Buczkówna] Boże Narodzenie $1981^{11}$

(...) śnieg nad zabitym chłopcem

i ubowcem

J. J. [Joanna Kulmowa ] Śnieg $r z a ̨ d z i^{12}$

Również w wierszu Adama Zagajewskiego Żelazo śnieg ma negatywne konotacje. Pojawiająca się tu metafora pokazuje wprowadzenie stanu wojennego jako „zmrożenie” nadziei:

(...) ciężki, ciemny śnieg zakrywa

kiełki marzenia ${ }^{13}$.

7 Okrestona epoka. Nowa Fala 1968-1993, opr. T. Nyczek, Kraków 1994, s. 318.

${ }^{8}$ Ida pancry na „Wujek”, „Wybór” z. 1-6, 13 grudnia 1981-17 marca 1982, Kraków [1982], s. 10.

${ }^{9}$ Poezja stanu wojennego..., s. 45.

${ }^{10}$ Poezja stanu wojny, s. 23.

$"$ Poezja stanu wojennego..., s. 81.

12 Na skrzyżowanitu Azji i Europy. Wiersze polskie 1980-1984, opr. S. Stelmachowa [A. Patrzałek, T. Patrzalek], Wrocław 1988 Oficyna Wydawnicza im. Grzegorza Przemyka.

13 Poezja starm wojennego..., s. 16. 
Śnieg - poprzez skojarzenie z całunem - wprowadza krąg metafor związanych ze śmiercią:

Stygnie umarły świat, w całun zamieci spowity.

[autor nieznany] Trzynasty grudnia ${ }^{14}$

„Jak całun” — w wierszu Karaska — ,jest grudniowa mgła”.

Również mróz służy do przenośnego określania sytuacji Polski po wprowadzeniu stanu wojennego. W Wigilii 81 Zagajewskiego pojawia się obraz zamarzającej ojczyzny:

Jeśli ojczyzna staje się bryłą lodu

i przymarza do niej chciwy wilgotny

język prośby, oddychaj, oddychaj

łapczywie jak mędrzec ${ }^{16}$.

Podobnie w wierszu Tomasza Jastruna Rozbitkowie:

Płyną ku ośnieżonym brzegom grudnia

Wycieńczeni głodni wolności

Z Polską zamarzniętą na ustach ${ }^{17}$

Częste są także pokrewne zamarzaniu obrazy zatrzymania, znieruchomienia:

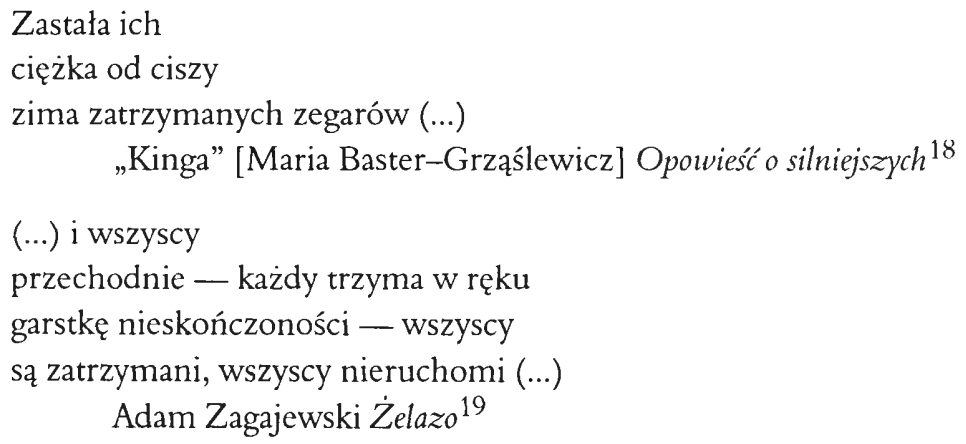

Najbardziej powszechny jest jednak obraz ciemnej, mroźnej nocy. Staje się on obiegową metaforą stanu wojennego:

${ }^{14}$ Zapomnisz...?, cz. 1: Polska pieta, Kraków 1984 Biblioteka Obserwatora Wojennego, s. 2.

Is 13 grudnia, [w:] „Noc generatów”. Zbiór poezji wojennej 13 XII 1981-13 II 1982, [Warszawa] 1982 Wojenna Oficyna Wydawnicza, s. 27.

${ }^{16}$ Poezja stanu wojennego..., s. 17.

${ }_{17}$ T. Jastrun, Biata lqka. Dziennik poetycki 9 listopada-23 grudnia 1982 roku, [Warszawa 1983] Biblioteka Tygodnika Wojennego [brak numeracji stron].

${ }_{18}$ Ida pancry na "Wujek", s. 8.

${ }^{19}$ Poezja stanu wojennego..., s.16. 
I noc przechodzi nad moją zniewoloną Ojczyzną

[autor nieznany] Grudniowa noca ${ }^{20}$

Czy uchowają się sprawiedliwi

Tej nocy ciemnej?

Ernest Bryll Koronka ${ }^{21}$

Noc, która jest jak wielkie czarne kowadło

Wszystkim nam na piersiach usiadła.

Anonim [Krzysztof Karasek] Pastoratka $1981^{22}$

Utwory posługujące się metaforą nocy i zimy wpisują się w tradycję zarówno romantycznej, jak i późniejszej poezji niepodległościowej, w której ogromną rolę odgrywało przeciwstawienie nocy (snu, grobu) oraz jasnego dnia (jutrzenki, świtu, wiosny). Jednakże w poezji stanu wojennego znacznie więcej jest opisów „nocy” niż zapowiedzi „świtu”. Dominuje poczucie, że:

(...) tak jeszcze długo do wiosny, i tak jeszcze długo do świtu! [autor nieznany] Trzynasty gridnia ${ }^{23}$

Jednakże do utartej symboliki wolności dołącza się tu nowy element — „sierpień”:

Sierpień nam nowym blaskiem był (...)

[autor nieznany] Robotnicza Rota ${ }^{24}$

Na pewno Bóg się wzruszy

waszą modlitwą prostą

i prędzej lody skruszy,

i Sierpień przyjdzie wiosną.

Małgorzata Grześ Kolysanka dla mojego syna ${ }^{25}$

\section{Mit pierwszej nocy}

W wielu utworach pojawia się szczegółowy opis pierwszej nocy stanu wojennego. Szczególnie często opisywane są sceny aresztowania. Aresztowanie odbywa się zwykle w tej samej scenerii - w nocy, na oczach płaczącego dziecka. Towarzyszy mu wyłamanie drzwi oraz wyrwanie ze snu:

20 „Noc generalów”..., s. 26.

21 Na skrzyżowaniu Azji i Europy..., s. 12.

22 Anonim [K. Karasek], Sceny z Grottgera i inne wiersze, [Warszawa] 1984 „Przedświt” Warszawska Niezależna Oficyna Poetów i Malarzy, s. 8.

${ }^{23}$ Zapominisz...?..., s. 2.

${ }^{24}$ Poezja stanu wojny, s. 70.

25. Na skrzyżouaniu Azji i Europy..., s. 48. 
Grudniową nocą roznosi się rozpacz i trwoga

Wyłamują drzwi, przerażone dzieci krzyczą w niebo.

[autor nieznany] Grudniowa nocą ${ }^{26}$

Przyszli nocą w uśpiony dom

Zabierali nas chyłkiem jak zbóje

Drzwi zamknięte otwierał łom

Idą, idą pancry na "Wujek".

[autor nieznany] Bez tytulu ${ }^{27}$

Przyszli o pierwszej w nocy

wyłamali drzwi łomem (...)

Jacek Bierezin Szkic do scen $z$ Grottgera ${ }^{28}$

W przytoczonych fragmentach zastanawia brak bliższego określenia, sprecyzowania, kim są ci, którzy „przyszli noca”. Wydaje się, że albo określenie takie nie jest konieczne do porozumienia z odbiorcą, który i tak doskonale wie z własnego doświadczenia, kim „oni” są, albo też - nie nazwani z imienia „oni” stają się w ten sposób groźniejsi, bardzicj wszechwładni.

Szczególnie mocno eksponowany jest w opisach aresztowania sen. Akcentuje się zwłaszcza bezbronność śpiących, a także brutalność przebudzenia. Włamanie się do domu w nocy oznacza pozbawienie prywatności:

Mogliby przecież i do snu twojego

Wedrzeć się nocą przez drzwi wyłamane...

[autor nieznany] Mniejsze $z 10^{29}$

„Wdarcie się do snu” sygnalizuje też, że została przełamana kolejna granica — jeszcze bardziej wewnętrzna niż drzwi domu - zniewolenie dotyka także ludzkiego umysłu, ludzkiego snu. To przekraczanie kolejnych granic pokazuje Zagajewski w wierszu Petit:

$$
\begin{aligned}
& \text { zdobyliście już huty i kopalnie, } \\
& \text { rozbiliście drzwi naszych } \\
& \text { mieszkań, idźcie dalej, teraz } \\
& \text { aresztujcie myśli }
\end{aligned}
$$

Motyw snu pojawia się także w Raporcie z oblężonego Miasta Zbigniewa Herberta. Tu jednak sen jest ostatnim, niezdobytym bastionem wolności:

26 "Noc generatów”..., s. 26.

${ }^{27}$ Dziękujemy generale. Wiersze, Warszawa 1982 Wydawnictwo im. Konstytucji 3 Maja, s. 13.

${ }_{28}$ Okrestona epoka..., s. 315.

${ }^{29}$ Idq pancry na "Wujek", s. 44.

30 Tamże, s. 27. 
i tylko sny nasze nie zostały upokorzone $\mathrm{e}^{31}$

Wyłamanie drzwi domu oznacza również, że dom przestał być bezpiecznym schronieniem. Powszechne jest poczucie zbezczeszczenia domu:

Kto to wali do drzwi

i przez łańcuch mówi że swój

i wchodzi w butach do środka sumienia (...)

Anna Kamieńska Grudzień $1981^{32}$

Pozbawienie domu drzwi powoduje wręcz zagładę domu — dom, który nie daje bezpieczeństwa, przestaje być domem:

Moje drzwi wyniesiono

trumnę z moim domem

niosło czterech milicjantów

Tadeusz Zygmunt [Paweł Mossakowski] Gdzie się podzialy moje drzwi? ${ }^{33}$

Skoro drzwi przestały oddzielać (jak w cytowanym wierszu T. Zygmunta) sferę prywatną od spraw publicznych, oznacza to też, że nie sposób się uchylić od zajmowania tym, co publiczne:

nie ma drzwi

więc nie ma domu

i dlatego muszę przeprowadzić się

do Polski

(tamże)

W zacytowanym fragmencie uwidacznia się niezwykle charakterystyczne dla omawianej poezji uwewnętrznienie spraw publicznych. W warunkach stanu wojennego sprawa publiczna staje się sprawą prywatną:

Lecz Polska nie zginęła, dopóki żyjemy

Została niezdobyta w każdym naszym domu (...)

[autor nieznany] Styczeń $82^{34}$

Dom staje się więc znów — jak w okresie zaborów - ostoją polskości.

Polska jest „w każdym naszym domu”, a jednocześnie Polska jest domem - domem, który został zagrożony:

31 Z. Herbert, Raport z oblężonego Miasta i inne wiersze, Wrocław 1992, s. 102.

32 Poezja stanu wojny, s. 29.

33 Na skrzyżowaniu Azji i Europy.., s. 13.

${ }^{34}$ Ida partory na ,Wujek”, s. 40. 
Ruina, kurz, popioły, dym

Podpalił ktoś sierpniowy dom (...)

[autor nieznany] „Ruina, kurz, popioly, dym... 35

Sierpień roku 1980 uczynił z Polski dom — wprowadzenie stanu wojennego zniszczyło wszystkie związane $z$ tym nadzieje.

\section{III. „Polska więzienna”}

Realia więzienne, a raczej realia związane $z$ internowaniem, stają się często tematem całych cykli poetyckich. Takjest w przypadku Wiktora Woroszylskiego (Dziennik internowania. Grudzień 1981-luty 1982, Biatołęka-Jaworze), Jana Polkowskiego (Ogien. Z notatek 1982-1983), Lothara Herbsta (Polska więzienna. Dziennik liryczny pisany od 16 lutego do 6 czerwca 1982 r. w Strzelcach Opolskich, Nysie, we Wroctawiu), Tomasza Jastruna (Biala laka. Dziennik poetycki 9 listopada-23 grudnia 1982 roku).

Zastanawia niemal kronikarski charakter tych rozbudowanych tytułów. Dokładne wyznaczenie miejsca i czasu służy prawdopodobnie podkreśleniu autentyczności opisywanych doświadczeń. Nieprzypadkowo też pojawiają się takie określenia jak „dziennik”, „notatki”. Wiele więziennych wierszy zbliza się w swej poetyce do dziennikowego zapisu, notatki utrwalającej „internatowe” realia, wydarzenia i rozmowy. Jak pisze Aleksander Fiut: „Powstaje wiersz-notatka. Sucha, wyprana z emocji, maksymalnie oszczędna. Stroniąca od patosu, a w zamian lekko zabarwiona ironią lub autoironią"36. Zupełnie tak, jakby więzienni „kronikarze" stosowali się do zasady:

unikam komentarzy emocje trzymam w karbach piszę o faktach ${ }^{37}$

Jedną z najczęściej opisywanych więziennych scenek jest spacer. Pobyt na tzw. „spacerniaku" stał się tematem wierszy Woroszylskiego (Spacer więźniów), Herbsta (Polska więzienna... 28), „Biernata” [Grzegorza Bieleckiego] (Na spacerniaku), Jastruna (Koło). Wspólną cechą tych utworów jest podkreślanie absurdalności chodzenia w kółko:

Wolno, nieustająco, we własnych lub więziennych kurtkach ze znakiem ZK

na plecach, krążymy dookoła spacerniaka (...)

oto my

mieszkańcy nowej planety absurdu

Lothar Herbst Polska więzienna... $28^{38}$

${ }^{35}$ Tamze, s. 39.

${ }^{36}$ A. Fiut, $W$ potrzasku, [w:] tenże, Pytanie o tożsamośc, Kraków 1995, s. 174.

${ }^{37}$ Z. Herbert, Raport z oblężonego Miasta, op. cit., s. 101.

${ }^{38}$ Poezja stanu wojennego..., s. 60. 
W cytowanym utworze chodzenie po spacerniaku jest zestawione $\mathrm{z}$ ruchem planet. Woroszylski odwraca tę metaforę:

Ziemia

szary więzień na kosmicznym spacerniaku

wydreptała znów kółko

i wróciła (...)

Byle do wiosny ${ }^{39}$

To odwrócenie nadaje niewoli charakter totalny — cały kosmos staje się więzieniem. Wiele wierszy podkreśla ten totalny charakter niewoli. Niewola nie ogranicza się wyłącznie do sytuacji fizycznego przebywania w więzieniu, gdyz - jak pisze anonimowy autor:

(...) nie ma żadnej różnicy

między tą a tamtą stroną krat

$G d y b y^{40}$

Wyjście z więzienia na wolność jest pozorne:

Wychodzą na wolność

Która brzmi ironicznie

Tomasz Jastrun Wolnośc ${ }^{41}$

W wierszu Jarosława Brody Lipiec-sierpien 1984 wyjście z więzienia oznacza powrót do „Wspólnej celi” ${ }^{42}$. Również w wierszu Leszka Szarugi ojczyzna jest porównana do „coraz ciaśniejszej celi" ${ }^{43}$. Polska jako więzienie jawi się także w nawiązującym do Hamleta wierszu Krzysztofa Karaska:

\section{Rację ma Szekspir \\ Polska jest więzieniem Anonim [Krzysztof Karasek] Z Szekspira ${ }^{44}$}

Również powrót Pana Cogito „na kamienne łono ojczyzny”45 jest powrotem do więzicnia.

Nieodłącznie związana z pobytem w więzieniu „cela” funkcjonuje w tej poezji także w odniesieniu do mieszkania.

Przechodzień z lękiem

Wczepionym w kark

\footnotetext{
39 W. Woroszylski, Lustro. Dziennik internowania. Tutaj, London 1984, „Aneks”, s. 48.

to Poezja stani wojny, s. 34.

41 T. Jastrun, Biala taka... [brak numeracji stron].

42 Na skrzyżouaniu Azji i Europy..., s. 27.

43 Jeszcze raz, [w:] Poezja stanu wojennego..., s. 26.

44 Tamże, s. 46.

${ }^{45}$ Z. Herbert, Pan Cogito-powrót, op. cit., s. 22.
} 
Biegł do celi

Swojego mieszkania 46

- pisze Jastrun. Zaś u Polkowskiego w wierszu pod znamiennym tytułem Wolny, w wolnym kraju obrazy celi i mieszkania nakładają się na siebie:

Patrzyłem jak żona kładzie talerz

na kuchennym stole i synek biegnie

przez szarą przed świtem

celę. ${ }^{47}$

Wśród więziennych realiów szczególne miejsce zajmuje zaokienny pejzaż. Na plan pierwszy wysuwają się w nim „znaki uwięzienia” - mur, drut kolczasty, psy, strażnicy:

Przez więzienne okno widać plac. Śnieg i glina

okolone betonowym murem

i drutem kolczastym.

$$
\text { Jan Polkowski Hymn }{ }^{48}
$$

za oknem beton

a na nim uzbrojony żołnierz

Anka Kowalska $Z$ listów cenzurowanych $2^{49}$

Ale ważne jest również to, co można zobaczyć za nimi — fragment nieba, las, czyli „zadrutowany horyzont" ${ }^{50}$. Oglądana przez więzienne kraty przyroda staje się jednak źródłem nadziei i siły. Tak jest m.in. w Spacerze i Celi 513 „Kielczanki” [Marii Przybylskiej], a także w Morzu Woroszylskiego.

Czasem próbuje się również nadać sens więziennemu doświadczeniu przez odniesienie go do płaszczyzny religijnej. Tak postępuje Polkowski w wierszu „Piotr szedt za Nim z daleka”, podobnie Maria Przybylska w utworze Nasz krzyż.

Dużą grupę utworów więziennych stanowią wiersze mające formę listu z internowania. Pisane do bliskich osób, wyrażają zarówno tęsknotę, jak i nadzieję na odmianę losu. Dla tego typu utworów często wzorem staje się popularna piosenka partyzancka:

Dziś do Ciebie przyjść nie mogę

Dla mnie dzisiaj celi mrok

Nie wyglądaj na mnie oknem

Próżno dziś wytężasz wzrok

[autor nieznany] „Dziś do Ciebie...”

\footnotetext{
${ }^{46}$ Do syna, [w:] Poezja stanu wojennego..., s. 21.

47 Tamże, s. 63.

48 Tamże.

${ }^{49}$ Zapomnisz...?..., s. 22.

50 L. Herbst, „Szary jesienny świt...”, [w:] Okrestona epoka..., s. 322.
} 
Parafrazowanie Leśnej kotysanki ma długą tradycję w okolicznościowej poezji politycznej — przy jej pomocy uzasadniono konieczność rozstania także w okresie strajków w roku 1970 i 1980.

Konwencja listu (zresztą - nie tylko listu z więzienia) pozwala na umieszczenie w utworze szeregu konkretnych, szczegółowych informacji przeznaczonych dla adresata listu:

Do Z. nie łaź. On strasznie się boi.

Raczej do tych, pamiętasz, po prawej.

Torbę weź, wiesz, tę w kuchni co stoi

Jutro u nich coś dla Was zostawię.

[autor nieznany] List ukrywajqcego się dziatacza NSZZ „Solidarnośe” do $\dot{z}$ on $y^{52}$

Nadaje to omawianym tekstom charakter autentycznych dokumentów. Jednocześnie tego typu utwory sygnalizują, że stan wojenny ingeruje w życie prywatne, narusza więzi rodzinne, rozdziela bliskich. Ofiarami tej sytuacji stają się przede wszystkim dzieci.

\section{IV. „Przyszły obywatel i żołnierz”}

To właśnie dzieci - przestraszone, bezbronne, pozbawione rodziców — są przez wprowadzenie stanu wojennego najbardziej pokrzywdzone. Bezbronność dziecka akcentują zwłaszcza wiersze opisujące scenę aresztowania:

Obudzili was - moi synkowie - wyłamując domu drzwi

W ciemną noc wywlekli ojca, ludzie z orłem, żądni krwi

Odpędzili z jasnych główek sny o łąkach kolorowych

Zacisnęli łańcuch strachu na serduszkach kryształowych

[autor nieznany] Moim synom ${ }^{53}$

Zastosowane w zacytowanym utworze, nawiązującym do Elegii o... [chtopcu polskim] Krzysztofa Kamila Baczyńskiego, zdrobnienia - typowe dla sytuacji rozmowy z dzieckiem potęgują kontrast między dziecięcą wrażliwością a brutalnymi realiami. Nieprzystawalność dziecinnych pojęć do stworzonej przez dorosłych tragicznej rzeczywistości pokazuje też anonimowy List do generata:

Szanowny Panie Generale!

Mój ojciec umarł miesiąc temu

W kopalni Wujek, po postrzale.

A siostra ciagle pyta - czemu?

\footnotetext{
${ }^{51}$ Dziektujemy generale..., s. 23.

${ }^{52}$ Poezja stanu wojny, s. 25.

${ }^{53}$ Idq pancry na "Wujek", s. 25.
} 
Ja też za dużo nie rozumiem,

Bo osiem lat to nie jest wiele,

I odpowiedzieć jej nie umiem,

Dlaczego ojca Pan zastrzelił. ${ }^{54}$

Wielokrotnie podkreśla się, że stan wojenny odebrał dzieciom prawo do normalnego, radosnego dzieciństwa. Nastrój zagrożenia przenika też do licznie w tej poezji reprezentowanych kołysanek:

Mój syneczku, mój kochanyś

śpij czujnym snem psa,

zbudzi nagle cię nad ranem

tupot butów w drzwiach.

Jacek Leszczyna Kolysanka ${ }^{55}$

Luli, luli mały synku

znowu czołgi stoją w Rynku

znowu szczerzą czarne paszcze

jak lat temu jedenaście

A w Raduni krwawa woda

Szkoda ludzi, Polski szkoda

[autor nieznany] Gdańska kotysanka dla wnuka Birkuta ${ }^{56}$

Podobnie jak kołysanki, również bajki pełne są grozy:

krwawią bajki w książkach dla dzieci

Anonim [Krzysztof Karasek] „krew krew na mundurze... „57

Wielokrotnie powtarza się stwierdzenie, że dzieci nie wierząjuż w bajki. Tak jest w Bezsenności Jastruna, podobnie w anonimowym wierszu „Po calutkim świecie chodzil kiedyś Bóg... „58. Stan wojenny spowodował zmiany w dziecięcej świadomości. Dzieci bawią się teraz inaczej. Oto jak bohater Tajnego spotkania $z M$. opowiada o urodzinach swojego syna:

A bal urodzinowy był udany

Dzieci bawiły się $\mathrm{w}$ internowanie

A na koniec

Rozstrzelały najmłodszego

Te Jot [Tomasz Jastrun] Tajne spotkanie $z M .^{59}$

54 Na skrzyżowaniu Azji i Europy..., s. 31.

55 Dziękujemy generale..., s. 19.

56 Zielona urona. Antologia poezji okresu stanu wojennego, wyb. i opr. D. Dąbrowska, Szczecin 1994, s. 169.

57 Poezja stant wojennego..., s. 21.

58 Zielona wrona..., s. 97.

${ }^{59}$ Poezja stanu wojny, s. 21. 
Chłopcy bawiący się w milicjantów pojawiają się także w wierszu Brylla Widok na park arkadia. Podobną charakterystykę dzieci odnaleźć można w Raporcie... Herberta:

ale z niejaką dumą pragnę donieść światu

że wyhodowaliśmy dzięki wojnie nową odmianę dzieci

naszc dzieci nie lubią bajek bawią się w zabijanie $(. . .)^{60}$

W omawianych utworach sporo miejsca poświęca się rozważaniom o przyszłości dzieci. Czasem pojawia się nadzieja, że następne pokolenie będzie żyło w wolnym kraju. Przeważa jednak przekonanie, że dzieci powtórzą los rodziców:

Zamknij synku, oczka ciemne

Będziesz znowu niósł kamienie

Będziesz miał stalowe pięści

By przypomnieć, by się zemścić

[autor nieznany] Gdańska kolysanka... ${ }^{61}$

W wierszu Woroszylskiego Brzuch Barbary N. nie narodzone jeszcze dziecko to:

jeszcze nie narodzony więzień

poczęty między zwolnieniem ojca

a zatrzymaniem matki

nie wciągnięty do rejestru internowanych

przyszły obywatel i żołnierz tego kraju ${ }^{62}$

Wnioski, jakie wypływają z przedstawionych przykładów, są dosyć zaskakujące. Realia stanu wojennego, nawet pojmowane jako swoiste i niepowtarzalne, są jednak w tej poezji opisywane wciąż przy pomocy tych samych obrazów i metafor. To zjawisko powoduje, że rzeczywistość przedstawiona w omawianej poczji niezwykle łatwo zmienia sic̨ (szczególnie w niektórych swoich aspektach — takich jak „pierwsza noc” czy „wojenna sceneria”) w rzeczywistość mitologiczną. Skonwencjonalizowany opis scen i wydarzeń powoduje, że zostają one przeniesione w sferę mitu, legendy — tym samym dokonuje się ich swoiste uwznioślenie, wręcz sakralizacja. Poezja przestaje, wbrew deklaracjom twórców, jedynie opisywać fakty, dąży natomiast do ich utrwalenia w formie zmitologizowanej — odpowiadającej zbiorowemu doświadczeniu społecznemu.

Danic temu doświadczeniu indywidualnego wyrazu, niezależnego od zbiorowych wyobrażeń, okazało się zadaniem niezwykle trudnym, także zc względu na pozycję, jaką w tym okresie zajmował poeta w świadomości społecznej. Jak zauważył Stanisław Barańczak:

6i) Z. Herbert, Raport z oblężonego Miasta..., s. 101.

${ }^{61}$ Zielona wrona..., s. 170.

${ }_{62}$ W. Woroszylski, Lustro..., s. 43. 
To, co jeszcze w końcu lat siedemdziesiątych było ironicznym głosem z ubocza, głosem znajdującego się w mniejszości dysydenta, jakim z natury rzeczy jest liryk - w ciągu 16 miesięcy Solidarności spotężniało w głos ogółu, zostało wzięte na serio i przyswojone przez większość społeczeństwa. (...) Uzyskane w ten sposób poczucie wspólnoty stało się dla wielu poetów wartością tak cenną, że zakłócić je, czy odrzucić wydawało się im rzeczą nie do pomyślenia — po tragedii grudnia 1981 było zresztą nie do pomyślenia również ze względów moralnych ${ }^{63}$.

Podobnie pozycję poety w tym okresie oceniał Czesław Miłosz:

Obraz artysty, pisarza, narzucony mu przez społeczeństwo i przez niego przyjęty, jest dla niego wysoce pochlebny w sensie moralnym, umieszcza go wśród sprawiedliwych. Jego odosobnienie w społeczeństwie tym razem wydaje się definitywnie skończone. Taka jednak integracja nie obywa się bez kosztów i, rzec można, sprzeczna jest $z$ samą zasadą nieufności sztuki wobec nowoczesnego społeczeństwa ${ }^{64}$.

Właśnie do kosztów owej integracji należy zaliczyć fakt, że omawiana poezja nie potrafiła wyjść poza to, co Barańczak nazwał „materiałem zbiorowego mitu"65.

A zatem poezja stanu wojennego, będąc „poezją zbiorowego, wspólnego doświadczenia" ${ }^{, 66}$, musiała nieuchronnie stać się poezją zbiorowych, wspólnych metafor.

${ }^{63}$ S. Barańczak, Zreprqwaryzować mit, [w:] tenże, Przed i po. Szkice o poezji krajowej przetomu lat siedemdziesiatych i osiemdziesiatych, Londyn 1988, s. 121.

${ }_{64}^{64}$ Cz. Miłosz, Szlachetnośc, niestety, „Kultura”, Paryż 1984, nr 9, s. 12.

${ }_{65}$ S. Barańczak, tamże.

${ }^{66}$ K. Zawrat [L. Szaruga], słowo wstępne do: Poezja stanu wojennego..., op. cit., s. 9. 